\title{
ANALISIS PENGARUH DIMENSI KOLOM DAN PENGGUNAAN DROP PANEL TERHADAP KEGAGALAN GESER PONS PADA STRUKTUR FLAT SLAB
}

\author{
Jordi Angriawan ${ }^{1}$ dan Leo S. Tedianto ${ }^{2}$ \\ ${ }^{1}$ Program Studi Sarjana Teknik Sipil, Universitas Tarumanagara, Jl. Letjen S. Parman No.1 Jakarta \\ Email: jordi.ang07@gmail.com \\ ${ }^{2}$ Program Studi Sarjana Teknik Sipil, Universitas Tarumanagara, Jl. Letjen S. Parman No.1 Jakarta \\ Email: leotedi@gmail.com
}

\begin{abstract}
ABSTRAK
Teknologi sudah berkembang dengan masif dan mempengaruhi metode pelaksanaan konstruksi pelat lantai. Salah satu inovasinya adalah flat slab. Flat slab adalah konstruksi struktur pelat beton bertulang yang mentransfer beban langsung ke kolom pendukung tanpa bantuan elemen balok. Kegagalan yang biasanya terjadi pada struktur flat slab ini adalah kegagalan geser pons yang diakibatkan karena gaya yang bekerja di sekitar kolom. Kegagalan geser pons dapat direduksi dengan penambahan penebalan di sekitar muka kolom (drop panel) atau dengan penambahan dimensi kolom. Pada pembahasan kali ini, dilakukan analisis untuk mencari besarnya gaya geser pons yang terjadi pada flat slab dengan menggunakan aplikasi berbasis metode elemen hingga. Gaya geser pons pada struktur flat slab akan dibandingkan pada dimensi kolom yang bervariasi, juga akan dibandingkan antara flat slab tanpa drop panel dan flat slab dengan drop panel. Pembahasan ini bertujuan untuk mengetahui pengaruh dimensi kolom dan penggunaan drop panel pada konstruksi flat slab terhadap kegagalan geser pons. Penelitian ini menggunakan metode elemen hingga dan metode analisis teoritis berdasarkan SNI. Kesimpulan yang didapat adalah penambahan dimensi kolom dan penggunaan $d r o p$ panel pada flat slab dapat mereduksi kegagalan geser pons.
\end{abstract}

Kata kunci: flat slab, drop panel, metode elemen hingga, geser pons.

\section{PENDAHULUAN}

Struktur flat slab atau yang dikenal sebagai pelat cendawan atau pelat datar merupakan salah satu inovasi dalam perkembangan struktur pelat. Struktur flat slab menurut (McCornac, 2000) adalah pelat beton pejal dengan tebal merata yang mentransfer beban secara langsung ke kolom pendukung tanpa bantuan balok, flat slab termasuk pelat beton dua-arah dengan capital, drop panel, atau keduanya. Kegagalan struktur yang dapat terjadi pada struktur flat slab ini adalah terjadinya keretakan pada daerah pertemuan kepala kolom dengan pelat. Hal ini terjadi karena ada gaya yang disebut dengan gaya geser pons pada kolom yang menekan pelat. Untuk mengurangi potensi kegagalan geser pons maka dilakukan penebalan atau yang biasa disebut dengan drop panel pada daerah kepala kolom supaya menambah ketahanan pada geser pons. Struktur flat slab menurut (Asroni, 2010) memiliki beberapa keuntungan yaitu fleksibilitasnya terhadap tata ruang; waktu pengerjaannya relatif lebih pendek; hal ini dapat dilihat dari proses pembuatan bekisting pelat yang langsung dapat dibuat merata secara keseluruhan tanpa harus membuat bekisting balok-baloknya terlebih dahulu; kemudahan dalam pemasangan instalasi mekanikal dan elektrikal; menghemat tinggi bangunan (tinggi ruang bebas lebih dikarenakan tidak adanya pengurangan ketinggian akibat balok dan komponen pendukung struktur lainnya); pemakaian tulangan pelat bisa dengan tulangan fabrikasi (welded wire mesh).

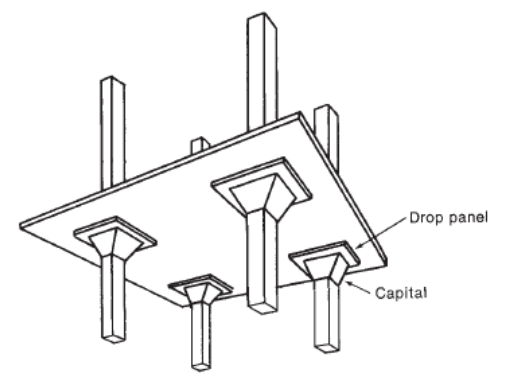

Gambar 1 Struktur Flat Slab

(sumber: Reinforced Concrete: Mechanics\&Design, James K. Wigh \& James McGregor (2011) ) 


\section{DASAR TEORI FLAT SLAB}

Kelemahan terbesar dari sistem konstruksi ini adalah kemampuan hubungan kolom-pelat dalam menahan gaya geser yang dapat menyebabkan penyebaran kerusakan secara horizontal dan menyebabkan pelat dapat runtuh atau lebih dikenal dengan geser pons (punching shear).

Perhitungan tegangan geser pons pada struktur flat slab dapat dihitung dengan menggunakan rumus:

$$
\sigma_{u}=\frac{V_{u}}{b_{o} \cdot d} \pm \frac{\gamma_{v} \cdot M_{u} \cdot c}{J_{c}}
$$

Keterangan :

$\boldsymbol{\sigma}_{\boldsymbol{u}} \quad=$ Tegangan geser pons $(\mathrm{MPa})$

$\mathrm{Vu} \quad=$ Gaya geser terfaktor $(\mathrm{N})$

$\mathrm{d} \quad=$ Tebal pelat efektif $(\mathrm{mm})$

bo $\quad=$ Keliling critical section $(\mathrm{mm})$

$\gamma_{v} \quad=$ Faktor reduksi Momen

$\mathrm{Mu} \quad=$ Momen terfaktor $(\mathrm{Nmm})$

\section{Kuat Geser Pelat}

Berdasarkan peraturan yang berlaku (SNI 2847:2013 Pasal 11:11.2.1), kekuatan geser pelat yang direncanakan harus sesuai dengan aturan sebagai berikut:

$$
\emptyset \mathrm{Vn} \geq \mathrm{Vu}
$$

Keterangan :

$\mathrm{Vu} \quad=$ Gaya geser terfaktor $(\mathrm{kN})$

$\mathrm{Vn} \quad=$ Kekuatan geser nominal $(\mathrm{kN})$

$\varnothing \quad=0.75$

Kuat geser nominal beton (Vc) untuk analisis geser pelat dua arah terhadap geser pons berdasarkan (sni 2847:2013 pasal 11:2) harus diambil nilai terkecil dari persamaan 3,4,dan 5

$$
\begin{gathered}
\mathrm{Vc}=0.17 \cdot\left(1+\frac{2}{\beta}\right) \cdot \lambda \cdot \sqrt{\mathrm{f}_{\mathrm{c}}{ }^{\prime}} \cdot \mathrm{b}_{\mathrm{o}} \cdot \mathrm{d} \\
\mathrm{Vc}=0.33 \cdot \lambda \cdot \sqrt{\mathrm{f}_{\mathrm{c}}{ }^{\prime}} \cdot \mathrm{b}_{\mathrm{o}} \cdot \mathrm{d} \\
\mathrm{Vc}=0.083 \cdot\left(\frac{\alpha_{\mathrm{s}} \mathrm{d}}{\mathrm{b}_{\mathrm{o}}}+2\right) \cdot \lambda \cdot \sqrt{\mathrm{f}_{\mathrm{c}}{ }^{\prime}} \cdot \mathrm{b}_{\mathrm{o}} \cdot \mathrm{d}
\end{gathered}
$$

Keterangan :

$\beta \quad=$ Rasio sisi panjang terhadap sisi pendek kolom, beban terpusat atau daerah reaksi.

$\alpha_{s} \quad=40$ untuk kolom interior, 30 untuk kolom tepi, 20 untuk kolom sudut.

\section{Drop Panel}

Jika drop panel digunakan pada struktur flat slab untuk mengurangi jumlah tulangan momen negatif pada kolom atau tebal pelat perlu minimum, syarat drop panel ditentukan pada peraturan (SNI 2847:2013 Pasal 13:2.5)

1. Menjorok di bawah slab paling sedikit seperempat tebal slab di sebelahnya; dan

2. Menerus dalam setiap arah dari garis pusat tumpuan dengan jarak tidak kurang dari seperenam panjang bentang yang diukur dari pusat ke pusat tumpuan dalam arah tersebut.

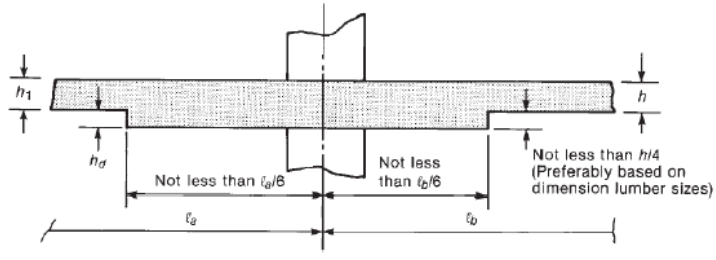

Gambar 2 Drop Panel

(Sumber: Reinforced Concrete: Mechanics\&Design, James K. Wigh \& James McGregor (2011) ) 


\section{METODE ELEMEN HINGGA}

Metode elemen hingga merupakan suatu pendekatan dengan metode numeris untuk menyelesaikan bentuk masalah teknis dan fisika dengan cara membagi objek tersebut menjadi bagian-bagian kecil lalu dianalisis dan hasilnya digabungkan kembali untuk mendapatkan penyelesaian keseluruhan atau yang dikenal dengan diskritisasi Metode elemen hingga dapat diterapkan pada masalah fisika yang luas, berhubungan dengan variabel dari aljabar, diferensial, atau persamaan integrasi. Contoh nyata penggunaan metode elemen hinga adalah untuk mendapatkan nilai tegangan pada penyelesaian bentuk geometris yang rumit, dikarenakan bentuk geometris yang rumit hampir tidak mungkin untuk diselesaikan Pada studi kasus ini digunakan aplikasi komputer berbasis metode elemen hingga untuk mendapatkan hasil yang presisi agar mengurangi risiko kesalahan dalam pengerjaannya.

\section{Pemodelan dengan Metode Elemen Hingga}

Studi kasus dilakukan pada panel pelat lantai dengan ukuran 24m x 24m, tebal pelat dengan ukuran 150mm. Jarak antar kolom yang digunakan adalah simetris $6 \mathrm{~m}$, tinggi kolom yang digunakan simetris $4 \mathrm{~m}$. Kuat tekan beton pada pelat dan drop panel yang digunakan adalah 30MPa dan 35MPa pada kolom. Analisis dilakukan pada dua tipe sturktur dengan drop panel dan tanpa drop panel, tujuannya untuk melihat perbedaan ketahanan terhadap geser pons di setiap kolom pada kedua tipe struktur. Pada struktur dengan drop panel, tebal drop panel yang digunakan adalah 200mm dan dengan ukuran $2 \mathrm{~m}$ x 2m. Berikut pada gambar 3 dan gambar 4 dijelaskan digambarkan tampak atas dan tampak 3D pada studi kasus kali ini.
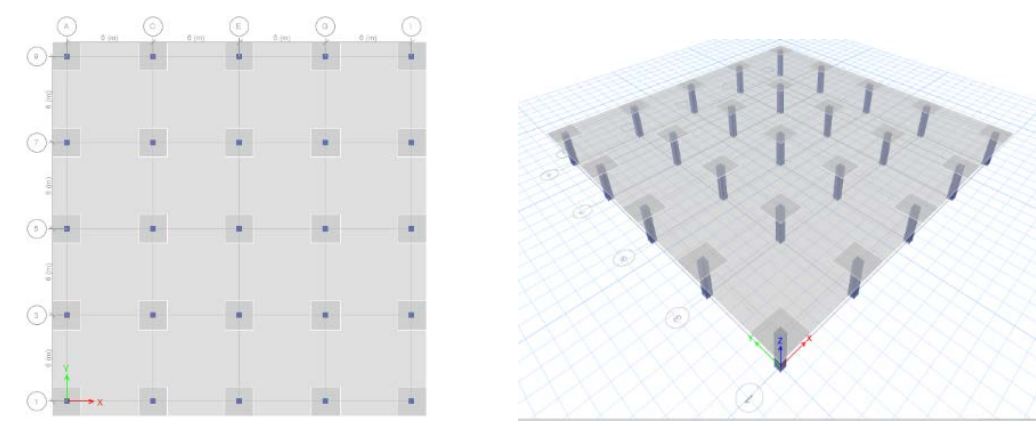

Gambar 3 Tampak Atas dan Tampak 3D Pemodelan Struktur Pertama
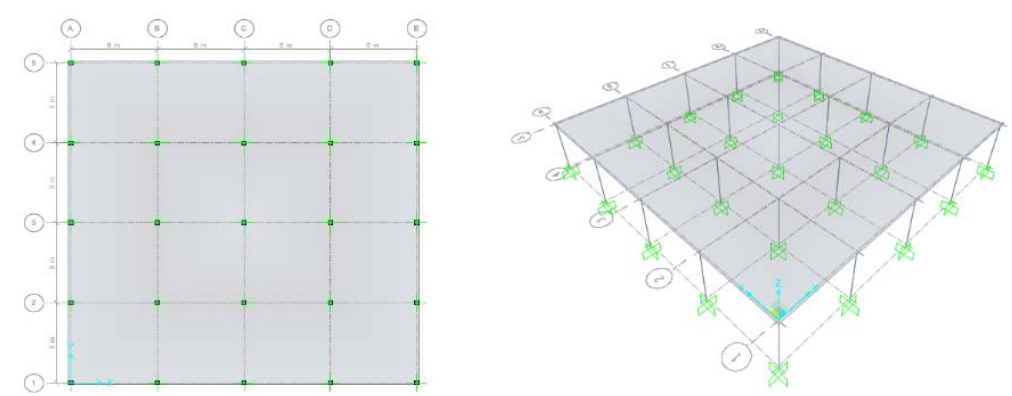

Gambar 4 Tampak Atas dan Tampak 3D Pemodelan Struktur Kedua

\section{Kondisi Batas}

Adapun batasan-batasan dalam penelitian kali ini adalah:

1) Analisis numerik, Metode Elemen Hingga menggunakan program berbasis metode elemen hingga

2) Peraturan yang digunakan sebagai acuan adalah SNI 2847:2013.

3) Studi difokuskan pada momen lentur dan gaya geser pons.

4) Tidak memodelkan penulangan pada struktur ini.

5) Mutu beton, tinggi kolom, ketebalan drop panel, serta ketebalan flat slab digunakan berdasarkan SNI 2847:2013. 


\section{ANALISIS DAN PEMBAHASAN}

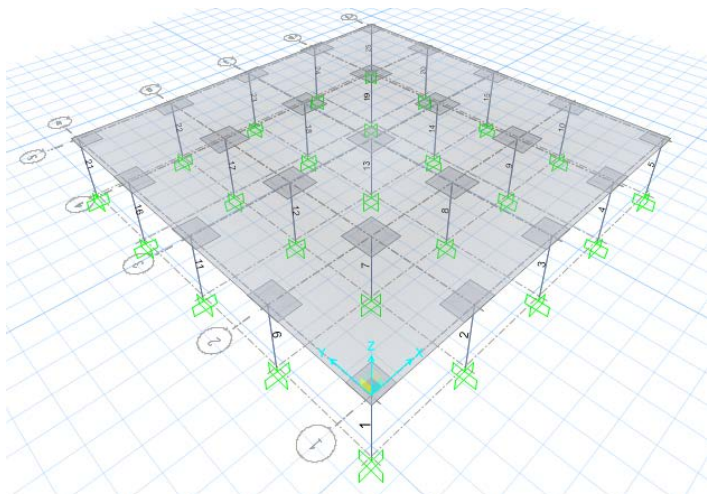

Gambar 5 Penomoran Titik Geser Pons

Pada struktur ini ada 25 kolom dengan ketinggian yang simetris 4m, dikarenakan bentuk panel pelat yang simetris, maka besarnya ketahanan geser pons pada beberapa muka kolom akan sama, sehingga diberikan penamaan tipe-tipe kolom yang mengalami nilai geser pons yang sama. Untuk penamaan kolom pada struktur ini adalah sebagai berikut:

Titik A $=$ kolom 1, 5, 21, dan 25

Titik B $=$ kolom 2, 4, 6, 10, 16, 20, 22, dan 24

Titik C $=$ kolom 3, 11, 15, dan 23

Titik D $=$ kolom 7, 9, 17, dan 19

Titik E $=$ kolom 8, 12, 14, dan 18

Titik $\mathrm{F}=$ kolom 13

Maka dari itu, analisis pada ketahanan geser pons selanjutnya akan ditinjau pada titik A, B, C, D, E, dan F.

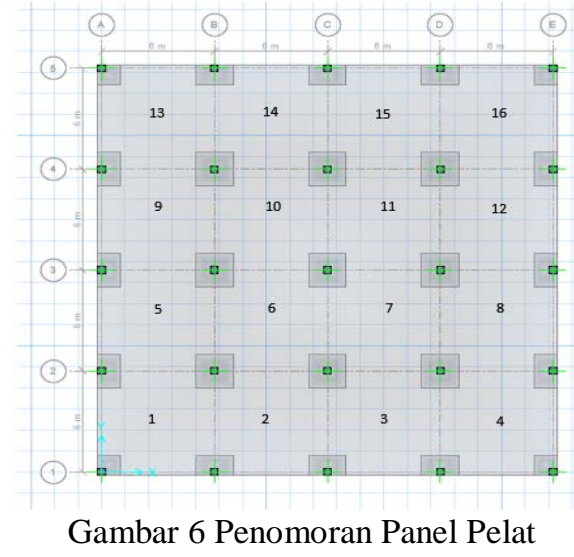

Pada struktur ini terdapat 16 panel pelat, dikarenakan bentuk panel pelat yang simetris, maka nilai deformasi maksimum serta letak deformasi maksimum pada beberapa panel akan sama, sehingga akan diberikan penamaan tipe-tipe panel yang mengalami nilai deformasi maksimum dan letak deformasi maksimum yang sama. Untuk penamaan panel pelat pada struktur ini adalah sebagai berikut :

Panel A = Panel 1, 4, 13, dan 16

Panel B = Panel 2, 3, 5, 8, 9, 12 ,14, dan 15

Panel C = Panel 6, 7, 10, dan 11

Maka dari itu, analisis pada nilai deformasi maksimum dan letak deformasi maksimum selanjutnya akan ditinjau pada panel A, B, dan C. 


\section{Persentase Peningkatan Ketahanan terhadap Geser Pons}

Rasio tegangan geser pons adalah perbandingan antara tegangan geser pons yang terjadi (diambil dari kombinasi pembebanan 1.2 DL + 1.6 LL) dengan tegangan kapasitas beton. Bila hasil rasio tegangan geser pons melebihi 1 , maka dinyatakan gagal karena tegangan geser pons yang terjadi melebihi tegangan tahanan geser beton. Berikut adalah tabel dan grafik hasil analisis dengan metode elemen hingga

Tabel 1 Geser Titik A,B, dan C dengan Metode Elemen Hingga

\begin{tabular}{|c|c|c|c|c|c|c|c|c|c|}
\hline \multirow{3}{*}{$\begin{array}{l}\text { Dimensi } \\
\text { Kolom } \\
(\mathrm{mm})\end{array}$} & \multicolumn{3}{|c|}{ TITIK A } & \multicolumn{3}{|c|}{ TITIK B } & \multicolumn{3}{|c|}{ TITIK C } \\
\hline & Rasio & & & Rasio & & & Rasio & & \\
\hline & $\begin{array}{c}\text { Tegangan } \\
\text { Geser } \\
\text { Pons }\end{array}$ & Status & $\begin{array}{c}\% \\
\text { Perbedaan }\end{array}$ & $\begin{array}{c}\text { Tegangan } \\
\text { Geser } \\
\text { Pons }\end{array}$ & Status & $\begin{array}{c}\% \\
\text { Perbedaan }\end{array}$ & $\begin{array}{c}\text { Tegangan } \\
\text { Geser } \\
\text { Pons }\end{array}$ & Status & $\begin{array}{c}\% \\
\text { Perbedaan }\end{array}$ \\
\hline 300 & 1.859 & Failed & - & 1.612 & Failed & - & 1.4005 & Failed & - \\
\hline 400 & 1.637 & Failed & 13.537 & 1.520 & Failed & 6.018 & 1.381 & Failed & 1.393 \\
\hline 500 & 1.282 & Failed & 27.735 & 1.298 & Failed & 17.082 & 1.199 & Failed & 15.236 \\
\hline 600 & 1.018 & Failed & 25.895 & 1.075 & Failed & 20.831 & 1.003 & Failed & 19.527 \\
\hline 700 & 0.934 & $O K$ & 9.005 & 0.846 & $O K$ & 27.024 & 0.823 & $O K$ & 21.865 \\
\hline
\end{tabular}

Tabel 2 Geser Titik D,E, dan F dengan Metode Elemen Hingga

\begin{tabular}{cccccccccc}
\hline \multirow{2}{*}{$\begin{array}{c}\text { Dimensi } \\
\text { Kolom } \\
(\mathrm{mm})\end{array}$} & $\begin{array}{c}\text { Rasio } \\
\text { Tegangan } \\
\text { Geser } \\
\text { Pons }\end{array}$ & Status & $\begin{array}{c}\text { TITIK D } \\
\text { Perbedaan }\end{array}$ & $\begin{array}{c}\text { Rasio } \\
\text { Tegangan } \\
\text { Geser } \\
\text { Pons }\end{array}$ & Status & $\begin{array}{c}\text { TITIK E } \\
\text { Perbedaan }\end{array}$ & $\begin{array}{c}\text { Rasio } \\
\text { Tegangan } \\
\text { Geser } \\
\text { Pons }\end{array}$ & Status & $\begin{array}{c}\text { TITIK F } \\
\text { Perbedaan }\end{array}$ \\
\hline 300 & 1.599 & Failed & - & 1.336 & Failed & - & 1.064 & Failed & - \\
\hline 400 & 1.254 & Failed & 27.554 & 1.085 & Failed & 23.143 & 0.910 & OK & 16.933 \\
\hline 500 & 1.007 & Failed & 24.510 & 0.897 & OK & 20.954 & 0.787 & OK & 15.616 \\
\hline 600 & 0.847 & OK & 18.936 & 0.769 & OK & 16.634 & 0.694 & OK & 13.434 \\
\hline 700 & 0.594 & OK & 42.545 & 0.562 & OK & 36.773 & 0.529 & OK & 31.019 \\
\hline
\end{tabular}

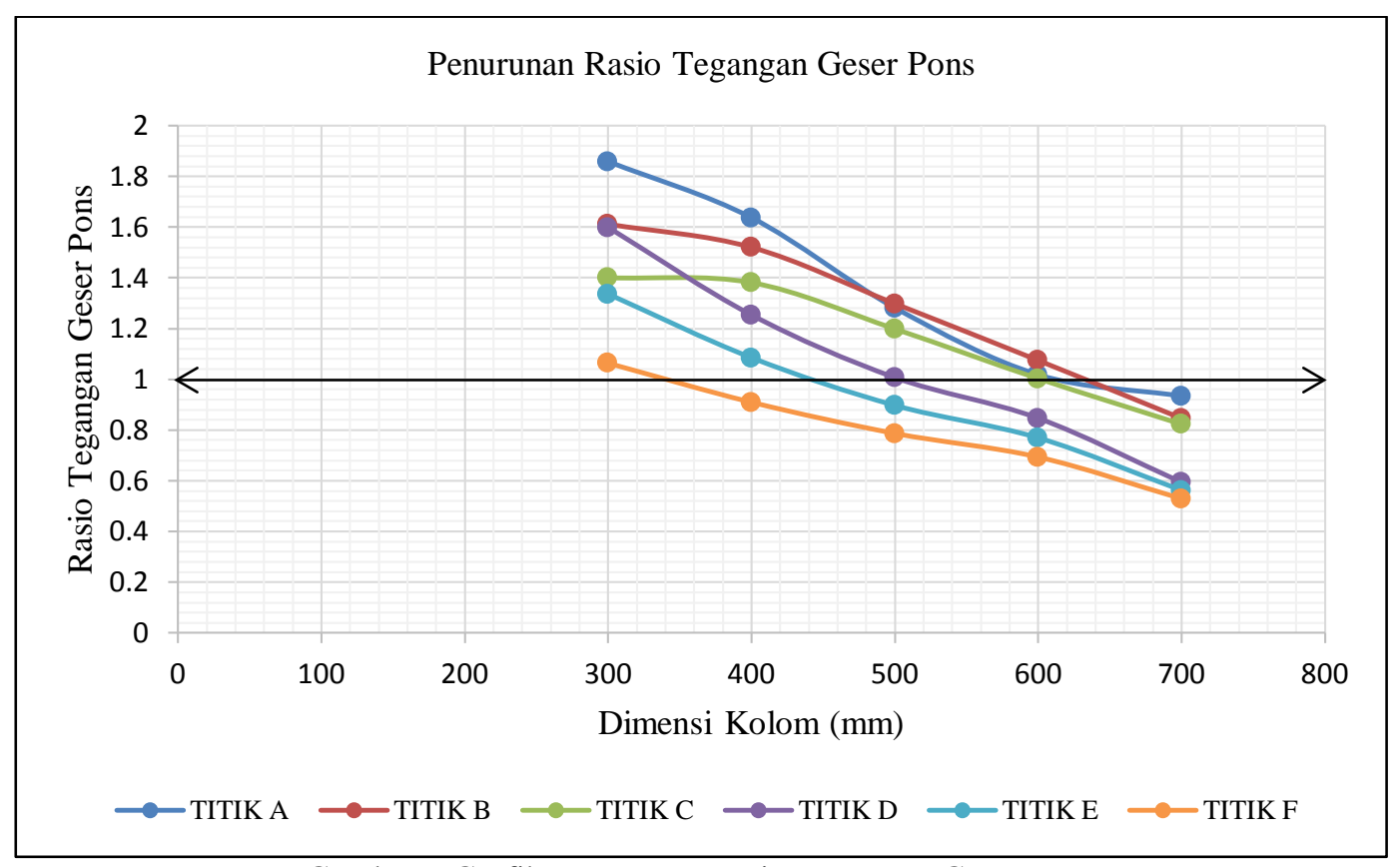

Gambar 7 Grafik Penurunan Rasio Tegangan Geser Pons

Berdasarkan hasil analisis dengan metode elemen hingga, dimensi kolom berpengaruh dalam memberikan kekuatan terhadap geser pons dengan rata-rata $20 \%$ setiap penambahan dimensi kolom sebesar 100mm, Garis hitam horizontal di angka 1 pada rasio tegangan geser pons menunjukkan batas kegagalan geser pons. 


\section{Pengaruh Penggunaan Drop Panel terhadap Geser Pons}

Berikut adalah grafik hasil analisis perbedaan rasio tegangan geser pons pada kasus 5 dan kasus 6 dengan metode elemen hingga:

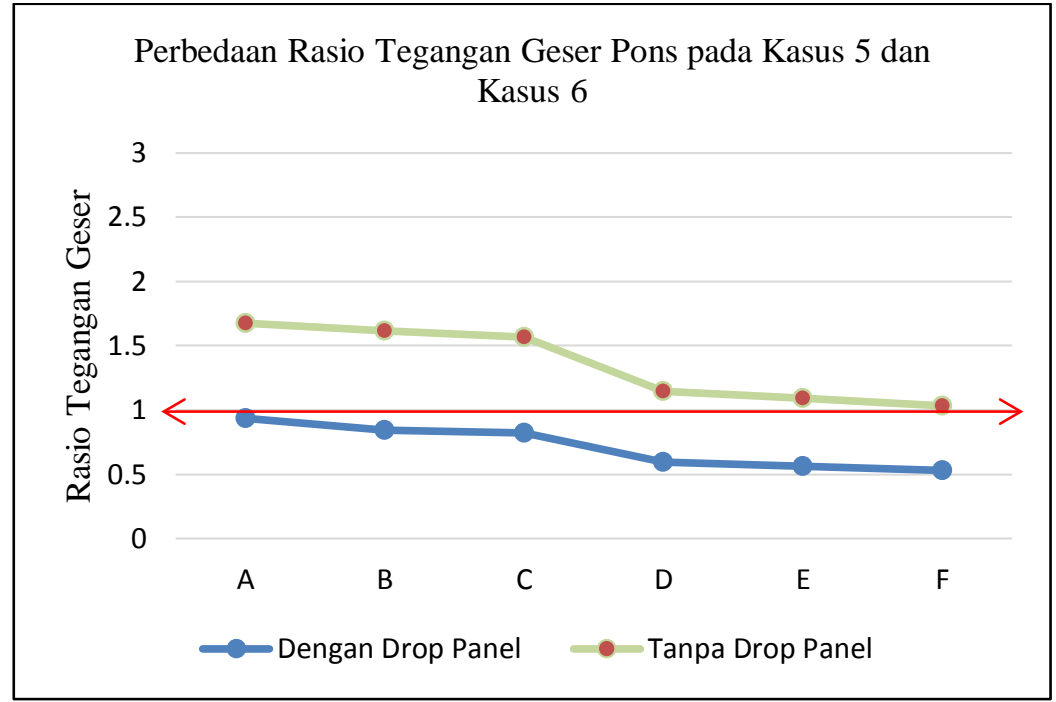

Gambar 8 Grafik Perbedaan Rasio Tegangan Geser Pons pada Kasus 5 dan Kasus 6

Penggunaan drop panel pada struktur flat slab terbukti secara signifikan terhadap kegagalan geser pons, dari grafik dapat dilihat nilai rasio tegangan geser struktur flat slab tanpa drop panel seluruhnya di atas satu yang artinya mengalami kegagalan geser pons pada setiap titik, namun pada struktur flat slab dengan drop panel tidak mengalami kegagalan geser pons di setiap titiknya. Penggunaan drop panel memberikan penambahan kekuatan terhadap geser pons dengan rata-rata $40 \%$.

\section{Pengaruh Penggunaan Drop Panel terhadap Lendutan}

Berikut adalah grafik hasil analisis perbedaan lendutan maksimum yang terjadi pada kasus 5 dan kasus 6 dengan metode elemen hingga:

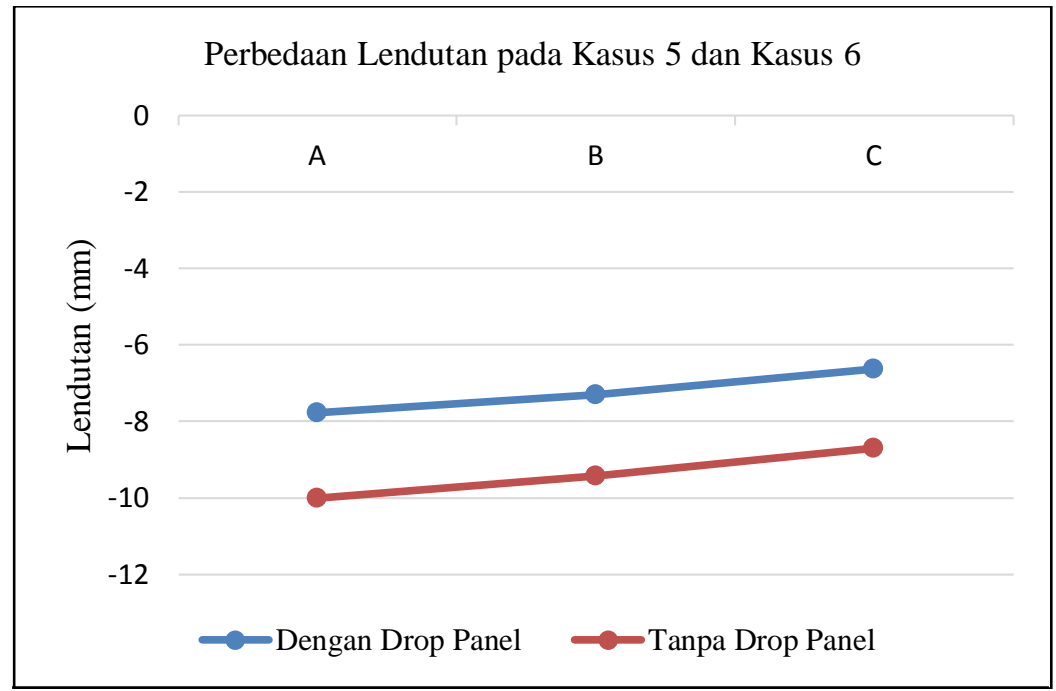

Gambar 9 Grafik Perbedaan Lendutan pada Kasus 5 dan Kasus 6

Berdasarkan hasil analisis dengan metode elemen hingga, penggunaan drop panel pada struktur flat slab dapat memberikan kekuatan terhadap lendutan. Terbukti pada Kasus 5 (kolom 700mm dengan drop panel) dan Kasus 6 (kolom 700mm tanpa drop panel). Penggunaan drop panel berpengaruh dalam memberikan kekuatan terhadap lendutan dengan rata-rata $29 \%$. 


\section{Perbandingan Hasil Analisis Metode Elemen Hingga dan Analisis Teoritis}

Berikut adalah perbandingan hasil tahanan geser pons berdasarkan analisis dengan metode elemen hingga dengan hasil analisis teoritis pada Kasus 6.

Tabel 3 Geser Pons Hasil Metode Elemen Hingga dan Analisis Teoritis

\begin{tabular}{|c|c|c|c|c|c|c|c|c|}
\hline \multirow[b]{2}{*}{ Titik } & \multicolumn{4}{|c|}{ METODE ELEMEN HINGGA } & \multicolumn{4}{|c|}{ ANALISIS TEORITIS } \\
\hline & $\begin{array}{c}\text { Tegangan } \\
\text { Geser } \\
\text { Pons } \\
(\mathrm{MPa})\end{array}$ & $\begin{array}{c}\text { Tegangan } \\
\text { Tahanan } \\
\text { Geser } \\
(\mathrm{MPa})\end{array}$ & $\begin{array}{c}\text { Rasio } \\
\text { Tegangan } \\
\text { Geser Pons }\end{array}$ & Status & $\begin{array}{c}\text { Tegangan } \\
\text { Geser } \\
\text { Pons } \\
(\mathrm{MPa})\end{array}$ & $\begin{array}{c}\text { Tegangan } \\
\text { Tahanan } \\
\text { Geser } \\
(\mathrm{MPa})\end{array}$ & $\begin{array}{c}\text { Rasio } \\
\text { Tegangan } \\
\text { Geser Pons }\end{array}$ & Status \\
\hline A & 2.026 & 1.208 & 1.677 & Failed & 2.07941 & 1.27311 & 1.63333 & Failed \\
\hline B & 1.929 & 1.195 & 1.614 & Failed & 2.04633 & 1.26039 & 1.62357 & Failed \\
\hline $\mathrm{C}$ & 1.875 & 1.195 & 1.569 & Failed & 1.9751 & 1.26039 & 1.56705 & Failed \\
\hline $\mathrm{D}$ & 1.343 & 1.17 & 1.147 & Failed & 1.3959 & 1.246 & 1.1203 & Failed \\
\hline $\mathrm{E}$ & 1.278 & 1.17 & 1.092 & Failed & 1.3212 & 1.246 & 1.06035 & Failed \\
\hline $\mathrm{F}$ & 1.211 & 1.17 & 1.035 & Failed & 1.275 & 1.246 & 1.02327 & Failed \\
\hline
\end{tabular}

Tabel 4 Perbedaan Geser Pons Hasil Metode Elemen Hingga dan Analisis Teoritis

\begin{tabular}{cccc}
\hline Titik & $\begin{array}{c}\text { Tegangan Geser } \\
\text { Pons (\%) }\end{array}$ & $\begin{array}{c}\text { Tegangan } \\
\text { Tahanan Geser } \\
(\%)\end{array}$ & $\begin{array}{c}\text { Rasio Tegangan } \\
\text { Geser Pons (\%) }\end{array}$ \\
\hline A & 2.548 & 5.1001 & 2.6893 \\
\hline B & 5.769 & 5.1837 & 0.6174 \\
\hline C & 5.047 & 5.1837 & 0.1441 \\
\hline D & 3.804 & 6.0451 & 2.385 \\
\hline E & 3.288 & 6.0451 & 2.935 \\
\hline F & 4.998 & 6.0451 & 1.115 \\
\hline
\end{tabular}

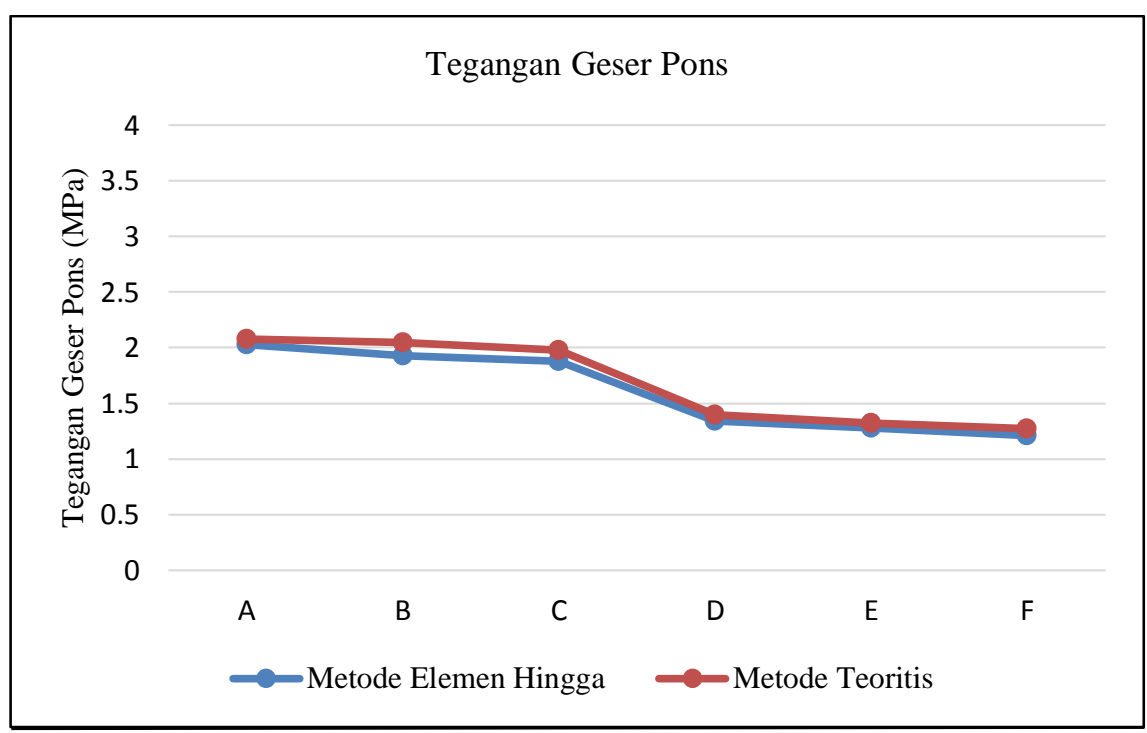

Gambar 10 Grafik Perbedaan Tegangan Geser Pons Analisis Metode Elemen Hingga dan Teoritis 


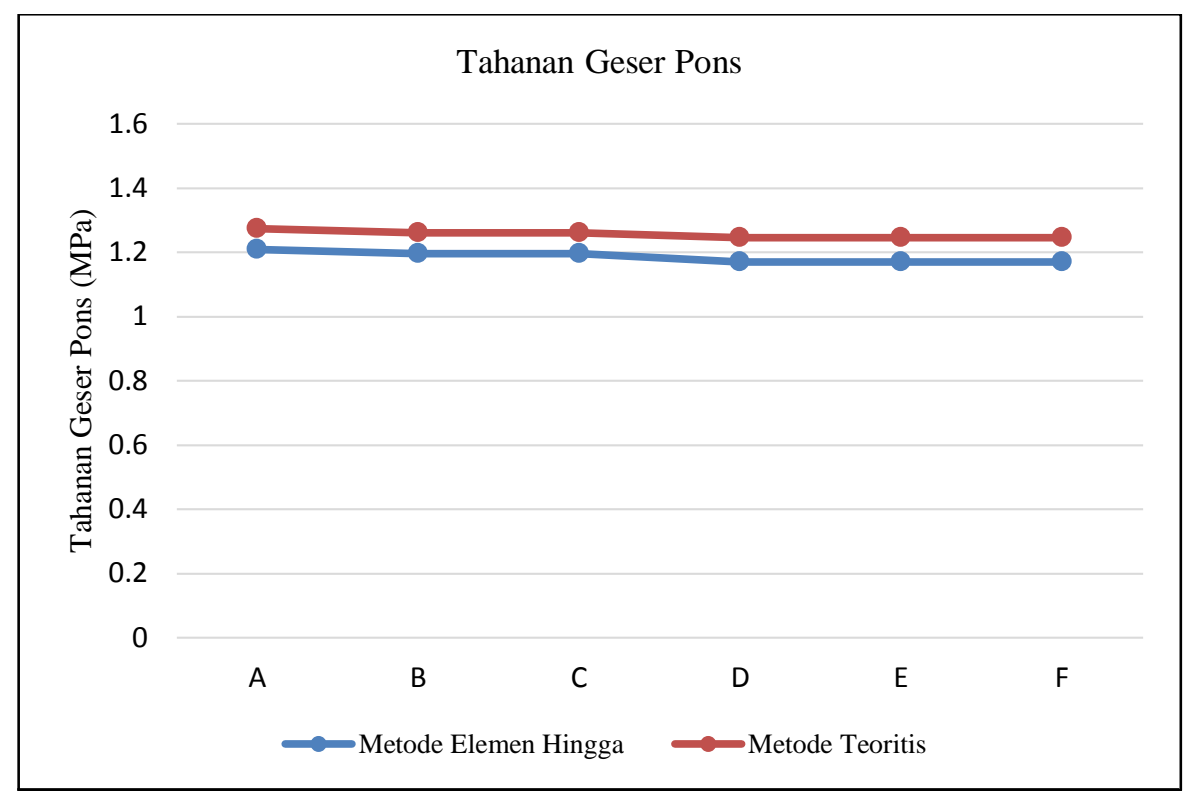

Gambar 11 Grafik Perbedaan Tahanan Geser Pons Analisis Metode Elemen Hingga dan Teoritis

Berdasarkan tabel dan grafik di atas, didapatkan hasil bahwa terjadi kegagalan geser pons karena tegangan geser pons yang terjadi melebihi dari tegangan tahanan geser pada beton. Didapatkan juga perbedaan pada metode elemen hingga dan perhitungan analisis, yaitu rata-rata $4 \%$ pada tegangan geser pons, $5 \%$ pada tegangan tahanan geser pons, dan $2 \%$ pada rasio tegangan geser pons.

\section{KESIMPULAN DAN SARAN}

\section{Kesimpulan}

Berdasarkan hasil analisis menggunakan metode elemen hingga dan analisis teoritis, diperoleh beberapa kesimpulan sebagai berikut:

1. Penambahan dimensi kolom dan penggunaan drop panel dapat menjadi pilihan untuk mengurangi risiko kegagalan geser pons pada struktur flat slab. Tapi penggunaan drop panel lebih signifikan dalam mereduksi tegangan geser pons yang terjadi pada struktur flat slab.

2. Analisis dengan metode elemen hingga menghasilkan perbedaan yang relatif kecil dibandingkan dengan analisis secara teoritis, dimana nilai tegangan geser pons rata-rata berbeda $4 \%$ dan tegangan tahanan geser rata-rata berbeda $5 \%$.

\section{Saran}

Berdasarkan proses pelaksanaan analisis ini, penulis memberikan saran untuk analisis selanjutnya:

1. Dapat dicoba untuk memperhitungkan gaya gempa.

2. Dapat dicoba untuk menggunakan jarak antar kolom yang bervariasi, apakah akan mempengaruhi nilai gaya geser pons dan lendutan.

3. Dapai dicoba untuk menggunakan bentuk penampang kolom yang bervariasi, apakah akan mempengaruhi nilai gaya geser pons dan lendutan.

\section{DAFTAR PUSTAKA}

Asroni, Ali. (2010). Balok dan Pelat Beton Bertulang, Yogyakarta : Graha Ilmu

Badan Standarisasi Nasional. (2013). Persyaratan Beton Struktural Untuk Bangunan Gedung. (SNI 2847:2013)

McCormac, Jack C. (2001). Desain Beton Bertulang Edisi Kelima Jilid 1 dan 2. Jakarta: Erlangga

Wright, J.K. dan MacGregor, J.G., (2012), Reinforced Concrete Mechanics and Design (Sixth Edition), New Jersey : Pearson Education Inc. 